\title{
The Efforts for Balancing Justice in the Distribution of Inheritance in Patrilineal Muslim Communities
}

\author{
M. Roem Syibly \\ Universitas Islam Indonesia \\ Yogyakarta, Indonesia. \\ roemsyibly@uii.ac.id \\ Ahmad Nurozi \\ Unversitas Islam Indonesia \\ Yogyakarta, Indonesia. \\ ahmad.nurozi@uii.ac.id
}

\author{
Sidik Tono \\ Universitas Islam Indonesia \\ Yogyakarta, Indonesia. \\ sidiktono@gmail.com
}

\author{
Amir Muallim \\ Universitas Islam Indonesia \\ Yogyakarta, Indonesia. \\ $834210101 @$ uii.ac.id
}

\begin{abstract}
Many Indonesian regions have strong patrilineal kinship systems; one of them is Batak Society. Batak Toba reflects it in all aspects of its social life, including in the case of inheritance. According to Batak customary law, male descendant (son) is entitled to receive family's inheritance, in contrary to female descendant (daughter). Male descendant is considered as hereditary carrier and clan successor from his parents. Nowadays, there is an awareness on avoiding discrimination to female descendant; therefore, there are efforts among heirs to share inheritance equally. The purpose of this research is to deliver explanations on the efforts of Muslim families in Batak Toba community in providing a sense of justice in the inheritance distribution between male and female descendants. This research was a descriptive research conducted in South Tapanuli regency. Respondents determined by purposive sampling technique, especially prominent figures and members of the community. Data were collected using library research and interview. The data were then analyzed by descriptive analysis. Results show that the efforts to balance the sense of justice was by providing effective inheritance for female descendant with balanced value to male descendant. Secondly, preparing grant and equally distributed family property before the heir passes away. Thirdly, filing lawsuit where female descendant files lawsuits to the court. In positive law, inheritors have equal right to their family's inheritance. Dynamics in community's inheritance system is a combination of customary, religious, and state laws. Maintaining family agreement in Batak Toba Muslim community is more important than letting family feud takes place because of unjust inheritance division.
\end{abstract}

Keywords: Batak Toba Custom, inheritance justice, Muslim community

\section{INTRODUCTION}

Customary law in Batak Toba is a resemblance of its kinship system, the patrilineal (male line) system, which puts emphasis on male line's position to its female line. Male descendant is the successor of his father's wealth; in contrary, female line will temporarily exist or even cease. Female descendant will marry another clan's descendant and become part of her new family. She remains part of her father's line as long as she is single (Elpina, 2015).

Batak Toba with its patrilineal system puts male descendant as heir. The main requirement in Batak Toba inheritance system is that male line (son) is entitled to his father's wealth. It indicates that male descendant automatically becomes a family's successor (Vergouwen, 2004 \& Sitorus, 2000). Inheritance can be given to female line (daughter) in the case of shared farmland or livestock, if she remains single or plans to get married, as well as assistance given to the eldest son of this female descendant (Elpina, 2015).

There are renown sayings in the community about its patrilineal system which primarily describe male superiority, for instance, dilaki ngenca berhak (male descendant is the one entitled to family inheritance), sidiberu la kenan (female descendant does not entitle to any of the wealth), diberu la banci erban taka (female cannot decide the share), and diberu la der kaipe (female descendant gets nothing) (Slaats and Portier, 1992).

Recently, family inheritance in Batak community has been brought to court as an effort to reach equality in inheritance distribution. Indonesian Supreme Court issued a regulation No. 179/K/Sip/1961 in 23 October 1961 to decline an appeal to the Supreme Court which stated that female descendants had equal rights to male descendants in terms of inheritance (Subekti, 1991).

A. Problem Formulation, Aims and Benefits of the Research

The statement of problem is; how the efforts for balancing justice in the distribution of inheritance of Batak muslim community? In this study, the researcher aims to identify the efforts for balancing 
justice in the inheritance distribution in Batak Toba Muslim community. It will provide details on the efforts made in the community; consequently, the results will not only generally give benefits to the development of customary law, but also the community itself which grows with the dynamics in it.

\section{METHOD}

The research employed descriptive-qualitative approach to examine a particular social phenomenon. The researcher worked on the secondary data before going to the field to attain primary data. The research mainly conducted in South Tapanuli regency where majority of the residents were Muslims of Batak Toba ethnic group. The participants were selected using purposive sampling technique. They were prominent figures and members of the community. Data collection was conducted with library research in which the researcher collected and analyzed provisions on civil law, especially on family and inheritance in customary law. Primary data obtained from the field mainly functioned to support it. Subsequently, the data were analyzed descriptively.

\section{RESEARCH FINDINGS}

\section{A. Inheritance Distribution System in Batak Toba Muslim Community}

With its patrilineal system, the Batak Toba community adopts similar system in terms of inheritance distribution. Male descendant will automatically inherit his father's wealth. On the other hand, female descendant receives a portion of her father-in-law's wealth in form of settlement or bequest.

There are three models of inheritance distribution in Batak Toba customary law. First, individual inheritance system allows wealth to be freely distributed according to the heir's will. Second, major male inheritance agrees on wealth distribution to only male descendants and maintained by the eldest son in a family. Finally, minor male inheritance lets the youngest son in a family to control and maintain the wealth (Sihotang and Sibarani, 1988).

The principles of inheritance in Batak Toba firmly state that only male line in a family that can obtain his father's wealth. However, female descendant can still receive a given fortune in form of farmland and livestock from his father. Additionally, an assistant can also be rewarded to the eldest son of the female descendant (Elpina, 2015).

Technically, inheritance distribution can be carried out when the heir is alive or already passed away. Inheritance distributed when an heir is alive is commonly shared only to male descendants; nevertheless, it does not indicate that none of the female descendants will receive any share. In Batak Toba, it is part of the local wisdom to share a piece of land to female descendants who already married and later, passed to her first son (Sihombing, 1986). According to holong ni ate (local institution), female descendant is entitled to her father's wealth as stated in Supreme Court decision Reg. No. 136 K/Sip/1967 in 31 January 1968.

When an heir has passed away, inheritance distributed under a particular term. Assets which belong to joint property can be used by his wife, owned throughout her life for the benefit of herself, and the continuation of her children's lives. Even though male descendant is the legal owner of his family's wealth, female descendant can still receive her share through Manulangi ceremony (Vergouwen, 2004), during her father's lifetime or after he deceased (Sihotang and Sibarani, 1988).

There are several reasons underlying patrilineal inheritance system that makes only male descendant entitled to inherit his family's wealth. First, tukor or dowry which resembles trade to a woman's life. Second, lakonan (levirate marriage) is a custom confirming that a widow can be inherited to her brother-in-law. Third, female descendant has no right to inherit her father's wealth. Finally, naki-naki (local sayings) defines woman as a tricky human being (Meliala, 1978).

There are also factors in patrilineal community which put male descendant in the top priority in its inheritance system, for instance, (a) family tree based on male line, (b) husband as the head of family, (c) children will bear their father's surname, (d) female descendant will not represent her parents, especially her father, and (e) in kalimbubu custom, male is considered capable to be parent, especially to be a mother (Suparman, 1985).

\section{B. A Shift in Inheritance System for Female Descendants}

The position of female descendant in terms of inheritance is still influenced by pure patrilineal system. There has been shift in the position of female descendants based on resolutions of the MPRS No. II/1960, the decision of Supreme Court No. 179K/Sip/1960, the decision of Supreme Court No. 179K/Sip/1961, and Law No. 1/1974 on marriage, with some influences on economics, politics, and knowledge development among people in Batak Toba community.

The resolutions of the People's Representative Council No. 11/1969, especially on item (c), mentions that wealth is given to the wife and children of the passing heir. Supreme Court in its decision No. 179K/Sip/1961 provides equal position among widow, male and female descendants of the passing heir, in terms of inheritance distribution. The verse 35 of Law No. 1/1974 illustrates that assets obtained during marriage are joint property and assets obtained as gift or inheritance belong to the respective owner. 
The aforementioned points have depicted the efforts to reach equality, justice, and humanity principles between male and female. Rationality factors have also played significant parts in the shifts of customary law in Batak Toba community, for instance, level of education, experience of overseas' living, social, and economic (Elpina, 2015).

The decision of Supreme Court No. 136K/Sip/1967 in 31 January 1968 approves the decision of High Court in practicing Batak customary law on Holong Ate or inheritance. It states that female descendant can receive a higher share of inheritance for the development of women's position and rights, either she lives in or stays outside the Batak neighbourhood. The decision of Supreme Court No. No. 103K/Sip/1971 in 31 July 1973 states that female descendant can be the only recipient of inheritance; thus, she has full access to the wealth left for her (Supreme Court No. 136K/Sip/1967). The aforementioned decisions are the actual efforts made to make sure quality between male and female descendants can be realized; however, there are still debates among experts in customary law (Komari, 2011).

\section{The Efforts for Balancing Justice in Batak Toba Muslim Community}

In Batak Toba community, key points in inheritance distribution lie on being the eldest or the youngest son in a family. Daughter, in any birth order, does not get any role in this issue; hence, it comes up as a discrimination to woman. Similarly, a son who is born neither as the eldest or the youngest cannot claim any share in the distribution process (Sinaga, 2018).

Recently, shift occurs among Muslims in Batak Toba community. Having male and female descendants is equally acceptable. In fact, parents will likely stay with their daughters after their retirement, compared to staying with their sons. Thus, Tulang Nainggolan asserts that discrimination between male and female descendants is no longer relevant (Sinaga, 2018).

The shift occurred among Muslims in Batak Toba is similar to Muslims in Karo, where female descendants are equal to the male ones. There are more members of Muslims in Karo community depart from its local customary law, as inheritance distribution is equally disseminated to both male and female descendants. Difference in the wealth division is no longer be based on gender; the community puts forward family agreement upon fair inheritance distribution (Tarigan,2014). The Muslims in Batak Toba community conduct the following efforts for balancing the justice.

1. Providing affective inheritance for female descendants with balanced value to male descendants. The basis and principle of inheritance distribution in Batak Toba are family agreements in which female descendants receive equal amount of the wealth as stated in Ruhutruhut adat Batak Toba (principles in Batak Toba). The principles mention that in the inheritance distribution, female descendant receives Hauma pauseang (land), Indahan Arian (a plot of land), Dondon Tua (inheritance from her grandfather), and Hauma Punsu Tali (a small plot of land) (Silaban, 2009). Therefore, by abiding the traditional Ruhut-ruhut adat Batak Toba, the Muslim community can provide affective inheritance that balanced with the sum of inheritance given to male descendant.

This model is supported by the decision of Supreme Court No. 942 K/Pdt/2012 based on Supreme Court Jurisprudence No. 179 K/Sip/1961 in 23 October 1961, Supreme Court Jurisprudence No. $415 \mathrm{~K} / \mathrm{Sip} / 1970$ in 16 June 1971, and Supreme Court Jurisprudence No. 707 K/Sip/1973 in 18 March 1973 about male and female offspring who have the same position as heirs and are entitled to get the same shares of the inheritance from their parents (Nainggolan, 2017).

2. Preparing grant and equally distributed family property before the heir passes away. In this Bataknese philosophy, social position of a female descendant will be highly valued in terms of receiving share from her parents-in-law. In other words, she receives grant. Batak Toba community uses two principles in inheritance distribution, family agreement and male line's basis; consequently, female descendant in the family obtains her share by receiving grant. An interesting progress appears in Batak Permalim kinship system where emotional bound takes part in the inheritance distribution. Thus, parents can share their wealth fairly to their children. This model is commonly carried before the heir passes away. Parents can equally share their wealth without gender obstruction. This system can also be found in Javanese and Bataknese society.

Individual inheritance system allows inheritor to receive his/her share according to the agreed portion. At the time the inheritance distributed, inheritor has the right to use, split, or even sell his/her share to fellow inheritor, relative, neighbor, or others. The characteristics of individual inheritance system is that inheritance shared to its inheritors according to Criminal Code and Islamic law. It happens in families with patrilineal system, for example, Javanese and Bataknese families (Sugangga, 1995).

3. Filing lawsuit. In this case, female descendant files a lawsuit. As in positive law, inheritordespite the gender-has the right to his/her 
parents' wealth. In general, the Supreme Court's ruling balances the portion of male and female's inheritance right on the disputes in Batak families. Some of the rulings are the decision of Supreme Court No. 179/K/Sip/1961, the decision of Supreme Court No. 100/K/Sip/1967, and the decision of Supreme Court No. 136/K/Sip/1967 (Nalle, 2018). In the cases that have been decided by the Supreme Court, Muslim families, especially their female descendants, can file lawsuits to court. Nevertheless, it may bring additional dispute to the family.

The researcher principally agrees to a statement by Victor W. Nalle (2018) which asserts that justice in inheritance distribution to male and female descendants should be bound to its social context of the community. For instance, in the case of land dispute; even though it can be divided equally to its female inheritors in the future, male inheritors possess higher social function upon the land. Similar function may apply to female inheritor who already marries a man from different clan or group. When she and her husband have financial problem, her brother should help her through the inherited land. Perspectives on evolving civilization can be a basis in changing inheritance distribution, especially for female descendants. Nonetheless, it should not deconstruct the relation between clan and land inherited to its male descendants. Land should not be placed as asset that can be divided to individuals in a family which merely be based on equality. It should be valued as clan's asset with collective function (Nalle, 2018).

\section{CONCLUSION}

Batak Toba community lives in patrilineal kinship system; hence, it counts on paternal lines in its life aspects. In terms of inheritance distribution, male descendant receives his share directly from his father and female descendant receives her share from her father-in-law. However, there has been a shift to the aforementioned system at the present time, especially among Muslims in Batak Toba community. They can accept the fact that female descendants are also entitled to their wealth. In reality, parents will likely stay with their daughters after their retirement, compared to staying with their sons. Thus, efforts are made to balance the justice in inheritance distribution. The Muslims in Batak Toba community establish affective inheritance for female descendants with balanced value to male descendants. Additionally, they also prepare grant and equally distributed family property before the heir passes away. Finally, female descendant in the Batak Toba Muslims community may file a lawsuit in settling inheritance dispute in her family.

\section{ACKNOWLEDGMENT}

The authors would like to acknowledge the financial support from Ministry of Research, Technology and Higher Education of the Republic of Indonesia under Hibah PDUPT year 2018 and also support from Directorate of Research and Community Service (DPPM), Universitas Islam Indonesia.

\section{REFERENCES}

[1] Elpina, Kedudukan Perempuan dalam Hukum Waris Adat Batak Toba, Kalam Keadilan, Jurnal Hukum, Volume 3 No. 2, June-December 2015

[2] Komari, Laporan Akhir Kompendium Bidang Hukum Waris, Badan Pembinaan Hukum Nasional, Depkumham, 2011.

[3] Meliala, Djaja Sembiring, Hukum Adat Karo dalam rangka Pembentukan Hukum Nasional. Bandung: Tarsito, 1978, p. 54

[4] Nainggolan, Yogius Pungu Parluhutan, Kedudukan Anak Perempuan Dalam Pewarisan Hukum Adat Batak Toba (Studi Kasus Putusan Mahkamah Agung Nomor. 942 K/Pdt/2012), Faculty of Law, Lampung University, Bandar Lampung, 2017.

[5] Nalle, Victor Imanuel W., Pembaharuan Hukum Waris Adat dalam Putusan Pengadilan. Jurnal Mimbar Hukum, Volume 30, Nomor 3, Oktober 2018, p.438

[6] Sihombing, M., Filsafat Batak (Tentang Kebiasaankebiasaan Adat Istiadat), Balai Pustaka: Jakarta, 1986, p. 82.

[7] Sihotang, Jaelani and Sibarani, Sadar, Pokok-pokok Adat Batak (Tata Cara Perkawinan di Toba), Mars 26: Jakarta, 1988 , p.77.

[8] Sihotang, Jailani and Sibarani, Sadar, Pokok-Pokok Adat Batak Toba, Mars 26: Jakarta, 1988.

[9] Silaban, Rudini TH, Pembagian Warisan Dalam Adat Batak Toba, Juni 7, 2009, in his personal blog; https://rudini76ban.wordpress.com/2009/06/07/pembagianwarisan-dalam-adat-batak-toba/

[10] Sinaga, Opung, a leading figure in Batak Toba community in 13 May 2018

[11] Slaats, Herman and Portier, Karen, Traditional Decision Making and Law, Yogyakarta: Gadjah Mada University Press, 1992, p. 113

[12] Subekti, R., Hukum Adat Indonesia dalam Yurispridensi Mahkamah Agung. Bandung: Alumni, 1991, p. 15-16

[13] Sugangga, I.G.N., Hukum Waris Adat. Semarang: UNDIP, 1995, p.11

[14] Suparman, Eman, Inti Sari Hukum Waris Indonesia. Bandung: Armico, 1985, p. 53-54.

[15] Supreme Court No. 136K/Sip/1967 in 31 January 1968

[16] Supreme Court No. No. 103K/Sip/1971 in 31 July 1973

[17] Tarigan, Azhari Akmal, Pelaksanaan Hukum Waris Di Masyarakat Karo Muslim Sumatera Utara. Jurnal Ahkam: Vol. XIV, No. 2, Juli 2014. hlm. 205

[18] Vergouwen, J.C., Masyarakat dan Hukum Adat Batak Toba. LkiS: Yogyakarta, 2004, p. 316 and 377

[19] Felix Sitorus, Hak Waris Janda dan Anak Perempuan Batak, Hukum dan Kemajemukan Budaya, E.K.M.Masinambow (ed.). Jakarta: Yayasan Obor Indonesia, 2000 p. 290-298. 